\title{
ФІЛОСОФСЬКІ ПРИНЦИПИ ПРОФЕСІЙНОЇ ПІДГОТОВКИ МАЙБУТНЬОГО ВЧИТЕЛЯ ПОЧАТКОВИХ КЛАСІВ
}

6. Korniiaka, O.M. (1995). Mystetstvo hrechnosti: Chy vmiiemo my sebe povodyty? [The art of buckwheat: Do we know how to behave?]. Kyiv, 96 p. [in Ukrainian].

7. Kravchuk, H.V. (2010). Metodyka navchannia studentiv tekhnichnykh spetsialnostei profesiino oriientovanoho anhliiskoho dialohichnoho movlennia na osnovi tekstiv naukovo-tekhnichnoi reklamy [Methods of teaching students of technical specialties of professionally oriented English dialogic speech on the basis of texts of scientific and technical advertising]. Candidate's thesis. Kyiv, 20 p. [in Ukrainian].

8. Pyz, A. (2003). Yazyk telodvizhenyi [Body language]. Moscov, 158 p. [in Russian].

9. Radevych-Vynnytskyi, Ya. (2001). Etyket i kultura spilkuvannia [Etiquette and culture of communication]. Lviv, 224 p. [in Ukrainian].

10. Tokarska, A.S. (2003). Kultura fakhovoho movlennia pravnyka [The culture of professional speech of a lawyer]. Lviv, 312 p. [in Ukrainian].

11. Toman, I. (1989). Mystetstvo hovoryty [The art of speaking]. Kyiv, 494 p. [in Ukrainian].

12. Uzhchenko, V.D. \& Uzhchenko, D.V. (2007). Frazeolohiia suchasnoi ukrainskoi movy [Phraseology of the modern Ukrainian language]. Kyiv, 293 p. [in Ukrainian].

13. Shevchuk, S.V. \& Klymenko, I.V. (2011). Ukrainska mova za profesiinym spriamuvanniam [Ukrainian language for professional purposes]. Kyiv, 694 p. [in Ukrainian].

Стаття надійшла до редакції 30.10.2020

УДК 378.011.3-051:373.3

DOI:

Іван Василиків, кандидат педагогічних наук, старший викладач кафедри математики, інформатики та методики їх викладання у початковій школі Дрогобицького державного педагогічного університету імені Івана Франка

\section{ФІЛОСОФСЬКІ ПРИНЦИПИ ПРОФЕСІЙНОЇ ПІДГОТОВКИ МАЙБУТНЬОГО ВЧИТЕЛЯ ПОЧАТКОВИХ КЛАСІВ}

У статті досліджуються наукові підходи до структурування методологічного аналізу педагогічноі діяльності. Використання дефініиії “ідентичність” у різних наукових сферах дає можливість створювати, диференціювати, систематизувати нові поняття та категорії. Особлива увага надавалася співвідносним категоріям, які органічно поєднанні між собою, дають уявлення про закономірності та інтегративний зв 'язок між ними, який виявляється у процесі пізнання. Шляхом онтологічного аналізу діалектичних законів і категорій визначено загальні методологічні принципи (засадничі ідеї, щуо формуються у процесі пізнання). конкретності, історизму, науковості, діалектичності.

Ключові слова: філософські принципи; вчитель початкових класів; ідентичність; науковість; категорії; професійна підготовка; філософія.

תim. 14.

Ivan Vasylykiv, Ph.D.(Pedagogy), Senior Lecturer of the Mathematics, Informatics and Methods of Teaching in Primary School Department Drohobych Ivan Franko State Pedagogical University

\section{PHILOSOPHICAL PRINCIPLES OF PROFESSIONAL TRAINING OF THE FUTURE TEACHER OF PRIMARY SCHOOL}

The article investigates the scientific approaches to structuring the methodological analysis of pedagogical activity. The use of the definition of "identity" in various scientific fields makes it possible to create, differentiate, and systematize new concepts and categories. The particular attention was paid to the relative categories, which are organically combined with each other; give an idea of the patterns and the integrative relationship between them, which is manifested in the process of cognition. By ontological analysis of dialectical laws and categories, general methodological principles (basic ideas formed in the process of cognition) are determined: concreteness, historicism, scientific, and dialectics.

The use of the principle of specificity reflects the relationship of all aspects of professional training of future teachers of primary school and the formation of their professional identity by means of information technology.

The principle of historicism makes it possible to move from an empirical description of facts to their theoretical generalization and to reveal the evolution of scientific ideas and views on the content and essential characteristics of professional training of future teachers of primary school.

The principle of science was used to form the conceptual thinking in future primary school teachers about the problems of identification and professional identity. 


\section{ФІЛОСОФСЬКІПРИНЦИПИПРОФЕСІЙНОЇПІДГОТОВКИ МАЙБУТНЬОГО ВЧИТЕЛЯ ПОЧАТКОВИХКЛАСІВ}

The implementation of the principle of dialectics is based on the definition of the main contradictions in the professional training of future primary school teachers, the solution of which contributed to the formation of professional identity in students of pedagogical Institutions of Higher Education.

Keywords: philosophical principles; primary school teacher; identity; scientific; categories; professional training; philosophy.

П остановка проблеми. Учителі $\epsilon$ центральною фігурою в системі сучасної історичної епохи, коли освіта $\epsilon$ основним механізмом відтворення духовності, культури, науки в суспільстві та формою існування людини їі соціалізації.

Наприкінці XX ст. освіта стала головним механізмом соціальних досліджень - соціальної генетики, передавання “генетичного коду”, культури, народу чи етнічним групам, ціннісно орієнтованих систем, досвіду попередніх поколінь.

Систематичний погляд на систему освіти склався як частина всебічної та рефлексивної революції людської цивілізації. Це частина процесу реалізації імперативу, щодо покращення відтворення якості освіти, включаючи вищу освіту.

Філософія педагогічної освіти як загальна філософія освіти - сфера, яка разом з еволюцією забезпечує особливу стійку основу, зберігає своє значення на кожному етапі розвитку людини. На думку В. Кременя, деякі з цих ідей набувають особливого значення під впливом певного процесу. Особливо в освіті з'являються нові ідеї, які необхідно враховувати, оскільки вони є важелем в педагогічній діяльності загалом [5, 335].

Аналіз останніх досліджень та публікацій. Аналіз наукової літератури показує, що для узагальнення та детального вивчення методологічного процесу вчені досліджують різні аспекти методології як науки, розкриваючи іiі функції, сутність та становлення. Для наукового з'ясування значення поняття "методологія" С. Мочерний обгрунтовує іï структуру [9]. У науковому дослідженні Г. Копилова було відстежено продовження досліджень $з$ цієї проблеми, оскільки автор розглядає “методологію та методологізацію в контексті часу" [4].

Особливе значення в контексті наукового аналізу філософсько-методологічних основ професійної підготовки майбутніх учителів мають праці, що розкривають методологію наукової діяльності [8].

В контексті вивчення різних аспектів підготовки викладачів у вищих навчальних закладах, майбутніх учителів початкових класів зосереджено увагу на обгрунтуванні В. Стьопіним філософських і методологічних аспектів соціально-гуманітарних дисциплін [13]; методологічного змісту педагогічного процесу, який визначався шляхом системного аналізу [6]; опрацювання методології педагогічного дослідження та на основі обгрунтування філософії практико-зорієнтованої методології педагогічної дії [2] тощо.

Мета статті. Дослідити філософські принципи професійної підготовки майбутніх учителів початкових класів.

Виклад основного матеріалу. Н. Гузій визначає сутність категорії професіоналізму в теорії та практиці у підготовці майбутніх учителів початкових класів виділяє наступні методологічні рівні: загальнофілософські, загальнонаукові, конкретно наукові, рівні методик і прийомів дослідження та методологічні рефлексії $[1,61]$.

Вважаємо що, інтегрувати наукові підходи для побудови методологічного аналізу педагогічної діяльності такими 4 рівнями:

1) Філософський дає змогу врахувати доктрину про науковий метод пізнавання парадигм i філософські принципи, щоб зрозуміти суть педагогічної діяльності.

2) Загальнонауковий відображає систему, яка використовує методологічні підходи при вивченні процесу формування професійної ідентичності майбутніх учителів початкових класів.

3) Конкретно-науковий 3'ясовує сутність психолого-педагогічних аспектів формування майбутньої професійної ідентичності вчителя.

4) Практично-технологічний демонструє оптимальні та ефективні педагогічні технології для реалізації окреслених цілей дослідження.

Філософська методологія у контексті формування професійної ідентичності майбутніх учителів початкових класів полягає у розумінні діалектичного процесу як складної форми становлення майбутнього вчителя початкових класів, якісної зміни у його формуванні та розвитку в процесі педагогічної діяльності.

Для створення логічно упорядкованої системи, що формує професійну ідентичність майбутніх учителів початкових класів, структуровано категоріально-понятійний апарат, який складається з сукупності понять (відображення у формі явищ і подій дійсності, зв'язків між ними шляхом фіксації їх загальних і специфічних ознак та якостей); термінів (слова, що представляють певне поняття спеціального наукового знання); категорій (“вершина” наукового пояснення, коли йдеться про нього, є найважливішим поняттям будь-якої науки, основа його понятійного апарату); 
дефініцій, що включає найважливіші особливості, у наукових текстах та спеціальних словниках і зафіксовано коротке, точне та логічне визначення певного поняття [7, 87].

Були розглянуті специфічні характеристики категоріально-понятійного апарату: розуміння наукових понять змінювалось діалектично залежно від контексту використання. Наприклад, суть дефінації “ідентичність” дещо змінилася і використовується у більш вузьких, більш конкретних поняттях із власним змістом та тлумаченням. Тому в соціології це соціальна ідентичність, у психології - Я-концепція, у педагогіці- формування професійної ідентичності, що грунтується на зображенні характерних рис кожного поняття. Тому використання дефінації “ідентичність” у різних наукових дисциплінах дозволяє нам створювати, диференціювати та систематизувати нові поняття, та категорії, що доповнюють категоріально-понятійний апарат.

Зокрема, вивчаючи питання професійної освіти, C. Сисоєва та I. Соколова визначають процес встановлення взаємозв'язків між новими поняттями як явище об'єктивації суб'єктивного тезаурусу [12, 33]. В контексті нашого дослідження сформувалася система понять, іiі головним стрижнем є розуміння професійної ідентичності та процесу професійної ідентифікації майбутніх учителів початкових класів.

Філософські методології, що формують професійну ідентичність майбутніх учителів початкових класів у процесі підготовки студентів до освітньої діяльності, базувалися на тому, що в дослідженнях використовувались універсальні філософські категорії: світ, матерія, буття, розвиток, рух, простір, час, суперечність, становлення, людина, свідомість, соціум, простірчас, норми суспільного співіснування тощо. Розглянуто основні риси філософської категорії:

- онтологічна (пізнання світу);

- гносеологічна (пізнання природи та суспільства);

- логічна (форма логічного мислення, при якій людина теоретично відображає реальність);

- методологічна (інструмент поглиблення знань, що є найважливішим елементом діалектики як методу).

Особлива увага приділена співвідносним категоріям, які органічно поєднуються між собою та дають ідеї для закономірностей, що виникають у пізнавальному процесі, та інтегрованих взаємозв'язків між ними. Такими співвідносними (“парність”, “полярність”) категоріями є: одиничне - загальне, система - елемент, сутність - явище, зміст - форма, причина - наслідок, необхідність
- випадковість, можливість - реальність [3]. Ці категорії складають тезаурус. Це добре розроблений масив знань для вивчення системи професійної ідентичності майбутніх учителів початкових класів, що є організацією інформації, найбільш тісно пов'язана із суспільством та їхнім становищем у “макро - та мікросоціальному просторі” $[11,29]$.

Вивчення формування професійної ідентичності майбутніх учителів початкових класів враховувало ключові філософські ідеї, які характеризується в сучасних філософських словниках як принцип, що визначає мету пізнання (за I. Кантом) і найвищим щаблем розвитку знань, що охоплює всі попередні форми знання і тому є вищою об'єктивною істиною (за Гегелем) [14, 407]. Філософські ідеї інтегрують думки та реальність стосовно різних факторів людського життя (сенс і спосіб життя, зміст та умови розвитку, особисті цінності та ідеали особистості тощо).

Закон діалектики та онтологічний аналіз категорій визначають загальні методологічні принципи (основні ідеї, що формуються в процесі пізнання): конкретності, історизму, науковості, діалектичності. На основі цих принципів, створювалися умови, для сприяння організації науково-знаннєвого масиву, котрі “"закріплюються, перевіряються та оновлюються в реальному житті на основі наукового підходу до вивчення конкретних явищ” [7, 92]. Зокрема, суть професійної ідентичності та методики іï формування використовують при підготовці студентів в педагогічних закладах вищої освіти.

Використання принципу конкретності відображає взаємозв'язок між усіма аспектами професійної підготовки майбутніх учителів початкових класів та формуванням їх професійної ідентичності за допомогою інформаційних технологій :

- вирізняти явища, особливо професійної ідентифікації у майбутніх учителів початкових класів від їх загальних характеристик на основі професійної підготовки студентів в педагогічних закладів вищої освіти та відтворення цього процесу як діалектично структурованого цілого на основі взаємозв'язку загального й одиничного;

- визначення та впровадження спеціальних психолого-педагогічних умов, що оптимізують формування професійної ідентичності майбутніх учителів початкових класів у професійній підготовці студентів педагогічних закладів вищої освіти;

- виявлення взаємозв'язків загального (застосування інноваційних педагогічних методик у професійній підготовці майбутніх учителів 


\section{ФІЛОСОФСЬКІПРИНЦИПИ ПРОФЕСІЙНОӤПІДГОТОВКИ МАЙБУТНЬОГО ВЧИТЕЛЯ ПОЧАТКОВИХ КЛАСІВ}

початкових класів) та одиничного (використання інформаційних технологій у формуванні професійної ідентичності майбутніх учителів початкових класів).

Принцип конкретності заснований на використанні таких методів, як дедукція, індукція, інтеграція та синкретизація.

Методологічне відображення саморозвитку особистості вчителя - це принцип історизму, який Н. Гузій пов'язує 3 певними історичними аспектами вивчення педагогічних явищ. Принцип історизму переходять від емпіричних викладів фактів до теоретичних узагальнень, що дає змогу визначити еволюцію наукових ідей та поглядів на зміст та суттєві характеристики професійної підготовки майбутніх учителів початкових класів, особливо до одиничного та навпаки, що сприяе науковій класифікації й типологізації певних явищ і систем [1, 70]. Ми у статті використовуємо принцип історизму для логічного взаємозв'язку між формуванням і розвитком терміну “професійна ідентичність", систематизації наукових знань із цієї проблеми в ретроспективі.

Принцип науковості використовувався у майбутніх учителів початкових класів для формування понятійного мислення 3 проблем ідентифікації та професійної ідентичності.

Генерування студентами систематизованого наукового понятійного мислення проявляється в тому, що майбутні вчителі використовують свої знання з основних наукових понять, здатні теоретично продемонструвати процес професійного розвитку на основі ідентифікації.

Оскільки професійна ідентичність як об'єкт пізнання - це нове багатогранне явище, засноване на принципі науковості, тоді майбутні фахівці зможуть визначити унікальні особливості вчителя, які $\epsilon$ важливими та необхідними для педагогічної професії.

Реалізація принципу науковості базується на використанні відповідних філософськометодологічних категорій, які допомагають з'ясувати суть основних понять та процесів у формуванні професійної ідентичності майбутніх учителів початкових класів:

- встановлення подібності в конкретному процесі з тієї ж причини відбувається за аналогією;

- верифікація використовується для визначення наукового пояснення конкретного тлумачення;

- категорії “впорядкованість” і “генералізація” особливо важливі для розвитку систем формування професійної ідентичності майбутніх учителів початкових класів, які логічно поєднують конкретні комплекси структурних елементів;

- розподіл важливих наукових ідей, їх аналіз, узагальнення та створення нових ідей здійснюються шляхом абстрагування, міркування та ідеалізації.

Реалізація принципу діалектичності базувалася на визначенні основних суперечностей у професійній підготовці майбутніх учителів початкових класів, розв'язання яких сприяло формуванню професійної ідентичності студентів педагогічних закладів вищої освіти. Для цього використовувались філософські категорії як аналіз (наприклад, традиційна освіта студентів); синтез (створення інноваційних технологій формування професійної ідентичності майбутніх учителів початкових класів); процеси (організація експериментальних досліджень) тощо. Діалектичний процес, що формує професійну ідентичність майбутніх учителів початкових класів, зумовлений необхідністю вдосконалення підготовки студентів та дає можливість використовувати принципи детермінізму [10, 188]. На основі принципу детермінізму можна виявити причинно-наслідковий зв'язок між впровадженням інноваційних методів підготовки майбутніх учителів початкових класів та формуванням їх професійної ідентичності. Визначення причинно-наслідкових зв'язків (принципу детермінація) визначає нові фактори, що сприяють розробці нових моделей навчального процесу та вдосконаленню професійної підготовки студентів в педагогічних закладах вищої освіти.

Головним у реалізації принципу детермінізму $\epsilon$ філософська категорії “причина” та “наслідок”, за допомогою яких пояснюється зумовленість усіх організованих інноваційних процесів у підготовці майбутніх учителів початкових класів, особливо формування в них професійної індентичності.

Висновок. Отже формування професійної ідентичності з урахуванням вищезазначених філософських принципів, покращать професійну підготовку майбутніх учителів початкових класів. Водночас впровадження розроблених систем у навчальний процес педагогічних закладів вищої освіти потребує впровадження загальнонаукових підходів до формування професійної ідентичності майбутніх учителів початкових класів за допомогою інформаційних технологій.

\section{ЛІТЕРАТУРА}

1. Гузій Н. В. Категорія професіоналізму в теорії і практиці підготовки майбутнього педагога: дис. д-ра пед. наук. Київ, 2007. 577 с.

2. Зязюн I. А. Філософія практико-зорієнтованої методології педагогічної дії. Педагогіка вищої ma середньої школи: зб. наук. пращь. Кривий Ріг: КДПУ, 2004. Вип. 8. С.3-12. 


\title{
ФІЛОСОФСЬКІПРИНЦИПИПРОФЕСІЙНОЇПДГОТОВКИ МАЙБУТНЬОГО ВЧИТЕЛЯ ПОЧАТКОВИХКЛАСІВ
}

\footnotetext{
3. Категорії філософіï. URL: http://estetica.etica.in.ua/ kategoriyi-filosofiyi/

4. Копылов Г. Г. Методология и методологизация в контексте времени. Кентавр. 1992. Вып.5. №1. С.6-11.

5. Кремень В. Г. Філософія людиноцентризму в освітньому просторі. 2 ге вид. Київ, 2011.520 с.

6. Кушнір В. А. Системний аналіз педагогічного процесу: методологічний аспект. Кіровоград: Вид. центр КДПУ, 2001. 348 с.

7. Мельничук I. М. Теорія і методика професійної підготовки майбутніх соціальних працівників засобами інтерактивних технологій у вищих навчальних закладах: дис. доктора пед. наук: спец. 13.00.04 “Теорія і методика професійної освіти”. Тернопіль, 2011. 585 с.

8. Методологія наукової діяльності: навч. посіб. / Д. В. Чернілевський, О. М. Гандзюк, В. І. Захарченко, I. М. Козловська та інші. Київ, 2008. 478 с.

9. Мочерний С. В. Поняття “методологія" та його структура. Психологія і суспільство. 2004. - № 3. С.5-24.

10. Ніка О. І., Шевченко Л. І., Хом'якО. І., Дем'янюкА. А. Новий словник іншомовних слів: близько 40000 сл. і словосполучень. Київ, 2008. 672 с.
}

11. Сисоєва С. О. Основи педагогічної творчості: підручник. Київ, 2006. 344 с.

12. Сисоєва С. О., Соколова І. В. Проблеми неперервної професійної освіти: тезаурус наукового дослідження: наук. видання. Київ, 2010. 362 с.

13. Степин В. С. Генезис социально-гуманитарных наук (философский и методологический аспекты). Вопросы философии. 2004. № 3. С.37-43.

14. Шинкарук В. І., Бистрицький С. К., Булатов М. О., Ішмуратов А. Т. Філософський енциклопедичний словник. Київ, 2002.742 с.

\section{REFERENCES}

1. Huzii, N. V. (2007). Katehoriia profesionalizmu v teorii i praktytsi pidhotovky maibutnoho pedahoha: dys. d-ra ped. nauk. [The category of professionalism in the theory and practice of training of future teachers]. Doctor's thesis. Kyiv, 577 p. [in Ukrainian].

2. Ziaziun, I. A. (2004). Filosofiia praktykozoriientovanoi metodolohii pedahohichnoi dii [Philosophy of the practice-oriented methodology of pedagogical action]. Pedagogy of higher and secondary school: coll. of science. work. Kryvyi Rih, Vol. 8. pp.3-12. [in Ukrainian].

3. Katehorii filosofii [Categories of philosophy]. Available at: http://estetica.etica.in.ua/kategoriyifilosofiyi/[in Ukrainian].

4. Kopylov, G. G. (1992). Metodologiya metodologizatsiya $\mathrm{v}$ kontekste vremeni [Methodology and methodologization in the context of time]. Kentavr, Vol.5. No.1.pp.6-11.[in Russian].

5. Kremen,V. H. (2011). Filosofiia liudynotsentryzmu v osvitnomu prostori [Philosophy of anthropocentrism in the educational space]. Second edition. Kyiv, 520 p. [in Ukrainian].

6. Kushnir, V. A. (2001). Systemnyi analiz pedahohichnoho protsesu: metodolohichnyi aspekt [The system analysis of the pedagogical process: a methodological aspect]. Kirovohrad, 348 p. [in Ukrainian].

7. Melnychuk, I. M. (2011). Teoriia i metodyka profesiinoi pidhotovky maibutnikh sotsialnykh pratsivnykiv zasobamy interaktyvnykh tekhnolohii $\mathrm{u}$ vyshchykh navchalnykh zakladakh [Theory and methods of professional training of future social workers by means of interactive technologies in higher educational institutions]. Doctor's thesis. Ternopil, 585 p. [in Ukrainian].

8. Metodolohiia naukovoi diialnosti: navch. posib. (2008). [Methodology of scientific activity: manual]. (Ed.). Chernilevskyi, D. V., Handziuk, O. M., Zakharchenko, V. I. Kozlovska, I. M. et al. Kyiv, 478 p. [in Ukrainian].

9. Mochernyi, S. V. (2004). Poniattia "metodolohiia" ta yoho struktura [The concept "methodology" and its structure]. Psychology and society. No. 3. pp.5-24. [in Ukrainian].

10. Nika, O. I., Shevchenko, L. I., Khomiak, O. I. \& Demianiuk, A. A. (2008). Novyi slovnyk inshomovnykh sliv: blyzko 40000 sl. i slovospoluchen [New dictionary of foreign words: about 40,000 words and phrases]. Kyiv, 672 p. [in Ukrainian]

11. Sysoieva, S. O. (2006). Osnovy pedahohichnoi tvorchosti: pidruchnyk [Fundamentals of pedagogical creativity: a textbook]. Kyiv, 344 p. [in Ukrainian].

12. Sysoieva, S. O. \& Sokolova, I. V. (2010). Problemy neperervnoi profesiinoi osvity: tezaurus naukovoho doslidzhennia: nauk. vydannia [Problems of continuing professional education: thesaurus of scientific research: science. edition]. Kyiv, 362 p. [in Ukrainian].

13. Stepin, V. S. (2004). Genezis sotsialnogumanitarnykh nauk (filosofskiy i metodologicheskiy aspekty) [Genesis of social sciences and humanities (the philosophical and methodological aspects)]. Questions of philosophy. No. 3.pp.37-43.[in Russian].

14. Shynkaruk, V. I., Bystrytskyi, Ye. K., Bulatov, M. O. \& Ishmuratov, A. T. (2002). Filosofskyi entsyklopedychnyi slovnyk [Philosophical encyclopedic dictionary]. Kyiv, 742 p. [in Ukrainian].

Стаття надійшла до редакції 06.10.2020

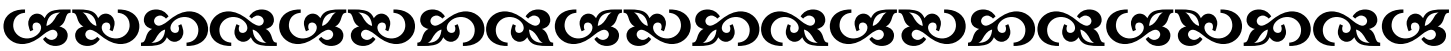

\author{
“ТІвориість, майстерність, досконалість - ие, насамперед, наполеглива праия". \\ Василь Сухомлинський \\ украӥнський педагог, публіиист, письменник, поет
}

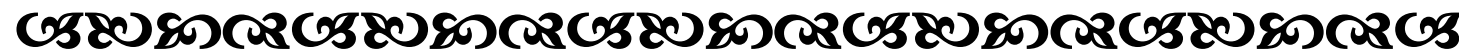

